species, except that there is a marked notch at the centre of the inner basal cingulum of the upper canines, visible in the buccal aspect of the teeth. The very considerable difference in the actual size of the teeth is shown in the following table :-

\begin{tabular}{|c|c|c|}
\hline Upper incisors, combined breadth at base . . & $\begin{array}{l}\text { perotis. } \\
\text { mm. } \\
3 \cdot 8\end{array}$ & $\begin{array}{l}\text { P. Trumbulli. } \\
\text { mm. } \\
3 \cdot 3\end{array}$ \\
\hline riorly $\ldots \ldots \ldots \ldots \ldots \ldots \ldots \ldots \ldots \ldots \ldots$ & $5 \cdot 3$ & $4 \cdot 0$ \\
\hline $\begin{array}{l}\text { Upper canine, greatest diameter at base, } \\
\text { horizontally ....................... } \\
\text { Large premolar and first two molars, com- }\end{array}$ & $3 \cdot 9$ & $2 \cdot 8$ \\
\hline $\begin{array}{l}\text { bined length } \ldots \ldots \ldots \ldots \ldots \ldots \ldots \ldots \ldots \\
\text { Lower canine, height from cingulum ex- }\end{array}$ & 8.5 & $6 \cdot 8$ \\
\hline ternally $\ldots \ldots \ldots \ldots \ldots \ldots \ldots$ & $5 \cdot 4$ & $4 \cdot 0$ \\
\hline irst lower premolar, transverse diameter. . & $2 \cdot 2$ & 1.5 \\
\hline rst lower molar, transverse diameter . .... & 2.5 & 1.9 \\
\hline
\end{tabular}

Specimens of $P$. per stis from Bolivia (Bridges) and Lagoa Santa (Reinhardt) have teeth agreeing closely in size with those of the example measured, which came from Cordova (White).

Forearm of the type (the epiphyses not yet fully united) 73 millim.

Hab. Para.

Type. Skin. B.M. no. 99. 11.2.1. Collected 7th June, 1898, and presented by J. Trumbull, Esq.

XXIII.-Notice of a Species of Paludestrina new to the British Fauna. By Edgar A. SMith.

In October last year Mr. Lionel P. Adams sent for my inspection a number of specimens of a very small species of Paludestrina which had been obtained in the canal at Dukinfield, Cheshire.

Three weeks later other specimens were forwarded to me by Mr. F. Taylor, of Oldham, who informed me that he was the first to discover the presence of this shell at the above locality.

It is certainly quite distinct from the other British species and at present has not been identified with any foreign form. It has been suggested by Mr. Adams and others that possibly it may be an introduction from North America, having been 
brought over in the same manner as Planorbis dilatatus and Physa heterostropha.

P. Brownii, Petterd, from Tasmania, more closely resembles this species than any other with which I am acquainted, and it is curious that the other species of Paludestrina (P. Jenkinsi), added of recent years to the British fauna, should also have an extremely close Tasmanian representative in P. Legrandiana of Brazier.

The present species may be thus described :-

\section{Paludestrina Taylori.}

Animal with the foot pale beneath, oblong, rounded behind, scmewhat auriculate anteriorly, with the front edge straightish or even slightly sinuated. Proboscis cleft beneath in front, blackish above and at the sides, pale at the end; body also blackish at the upper part of the sides. Tentacles moderately long, scarcely tapering, rather obtuse at the tips, semitransparent, with a dark streak on one or both sides; eyes coalblack, large, slightly prominent at outer base of tentacles, with a sulphur-coloured spot above each.

Shell subcylindrical, turreted, umbilicated, brownish or olive horn-colour, obscured by a blackish earthy deposit; whorls four in number, very convex, separated by a deep suture, clean specimens exhibiting fine lines of growth; aperture broadly ovate, a little narrowed above; peristome continuous, outer margin simple, columellar edge slightly thickened and faintly reflexed.

Length $2 \frac{1}{2}-3$ millim., diam. $1 \frac{1}{3}$.

Operculum paucispiral, thin, horny, slightly concave exteriorly.

The sulphur spots above the eyes are a very striking feature in this mollusc, and under the microscope have a granular and even almost luminous aspect. The small size, besides the other characters mentioned, readily distinguish this from the other British species. I have much pleasure in associating with this form the name of its discoverer.

\section{XXIV.-New South-American Sciuri, Heteromys, Cavia, and Caluromys. By Oldfield Thomas.}

Sciurus griseogena meridensis, subsp. n.

Precisely similar in size and general colour to the typical form, but the fur very much longer (hairs of back about 


\section{$2 \mathrm{BHL}$ Biodiversity Heritage Library}

Smith, E. A. 1901. "XXIII.-Notice of a species of Paludestrina new to the British Fauna." The Annals and magazine of natural history; zoology, botany, and geology 7, 191-192. https://doi.org/10.1080/00222930108678456.

View This Item Online: https://www.biodiversitylibrary.org/item/84522

DOI: https://doi.org/10.1080/00222930108678456

Permalink: https://www.biodiversitylibrary.org/partpdf/63721

\section{Holding Institution}

Smithsonian Libraries

\section{Sponsored by}

Smithsonian

\section{Copyright \& Reuse}

Copyright Status: Public domain. The BHL considers that this work is no longer under copyright protection.

This document was created from content at the Biodiversity Heritage Library, the world's largest open access digital library for biodiversity literature and archives. Visit BHL at https://www.biodiversitylibrary.org. 